\title{
Predictive Factors for the High Perianal Fistula Recurrence After Placement of Seton
}

\author{
Mohammed Sobhy Taema, Abd El Fattah Morsi Saied, Mustafa Mohammed Ahmed EL Sheikh \\ Department of General Surgery, Faculty of Medicine - Al-Azhar University
}

\begin{abstract}
Background: The placement of seton is one of the common sphincter-saving procedures for high fistula-in-ano (FIA). It has been described since Hippocrates who first used horse hair as a seton for the treatment of anal fistula. Objective: The aim of this study is to investigate the predictive factors for recurrence and to evaluate the efficacy and complications of seton treatment for high transsphincteric perianal fistula.

Patients and methods: Our study was a prospective study, on a sample size of 50 patients (43 males and 7 females) of high perianal fistula, carried out in Bab-Alsharia University Hospital.

Results: In our study $66.7 \%$ of recurrent cases had history of previous fistula surgery. Fecal incontinence was recorded in 3/50 (6\%) patients in our study. Factors associated with higher rates of fecal incontinence (FI) after fistula surgery included high transsphincteric or suprasphincteric fistula, horse-shoe fistula, female patients, and patients older than 45 years.

Conclusion: Factors that significantly predicted the recurrence of FIA were previous fistula surgery, anterior anal fistula, and presence of secondary tracks or branches as with supralevator extension, and horse-shoe fistula. Female patients and horse-shoe fistula were the significant risk factors for developing FI after the placement of seton.
\end{abstract}

Keywords: High Perianal Fistula Recurrence, Placement of Seton.

\section{INTRODUCTION}

An anal fistula is an abnormal track between the anal canal mucosa and the perianal skin. The usual history of this condition consists of an intermittent pain, itching, and discharge of pus, feces or blood ${ }^{(\mathbf{1})}$.

The vast majority of anal fistula are secondary to infection of the anal gland which presents as perianal abscess, which may spontaneously burst or inadequately drained (2). Other causes of perianal fistula include; inflammatory bowel disease, trauma, fungal or mycobacterial infection and neoplasm ${ }^{(3)}$.

The most comprehensive and practical classification and the one most widely used presently is that devised by Sir Alan Parks who classified perianal fistula according to its location to anal sphincter muscle into four main groups: intersphincteric, transsphincteric, suprasphincteric or extrasphincteric. These groups can be further subdivided according to the presence and course of any extensions or secondary tracks ${ }^{(4)}$.

Surgical treatment remains the gold standard for the management of anal fistula in adults as it achieves adequate drainage of infection and complete eradication of the fistulous track ${ }^{(5)}$. In contrast to pediatric FIA which can resolve spontaneously with conservative treatment ${ }^{(\boldsymbol{6})}$.

The surgical treatment of FIA varies according to the type of fistula; for simple fistulas lay open of the track is usually sufficient reaching a success rate of around $90 \%$. Complete excision of the track or fistulectomy is another option for the treatment of simple FIA; however, the larger wound of fistulectomy takes longer to heal and does not provide distinct advantages over fistulotomy regarding the incidence of recurrence of fistula ${ }^{(7)}$.

For the more complicated types of FIA that involves parts of the anal sphincter complex, other modalities of surgical management were advocated. These surgical modalities include single or two-stage seton, advancement flap techniques and ligation of intersphincteric fistulous tract (LIFT) ${ }^{(8)}$.

Currently, several different materials have been used as setons, including silk, braided silk, rubber band, silastic tube, linen, polypropylene, braided polyester, vascular loop, nylon, cable tie, and others (9).

There is a continuing demand to decrease the complications associated with seton use. The most common weak points of this technique are the high rates of continence disturbances, prolonged discharge and numerous visits to check and adjust the seton. The tight (cutting) seton is any string-like material which when passed and tied within the fistula track develops gradual transection of the external sphincter muscle as a result of pressure necrosis with a negligible splitting of the cut ends. In this way, it preserves sphincter continuity during the cutting process ${ }^{(\mathbf{1 0})}$.

\section{AIM OF THE WORK}

The aim of this study is to investigate the predictive factors for recurrence and to evaluate the efficacy and complications of seton treatment for high transsphincteric perianal fistula.

\section{PATIENTS AND METHODS Patients:}

A prospective study, on a sample size of 50 patients of high perianal fistula, carried out in BabAlsharia University Hospital.

\section{Inclusion criteria:-}

- Patients with high perianal fistula.

Exclusion criteria:-

- Patients with synchronous anorectal problems 
like hemorrhoids.

- Patients with fistula secondary to inflammatory bowel disease, malignancy, tuberculosis or trauma.

- Patients with existing preoperative incontinence.

\section{Methods:}

A-Full history and clinical examination:

Full medical history and clinical data were obtained from each patient with special emphasizes on the presenting symptoms.

- Digital rectal examination was done to establish a diagnosis.

- Continence status of the patients of the study was assessed by Wexner incontinence score system (11).

B- Preoperative investigations: routine preoperative evaluation

- Complete blood count.

- Coagulation profile.

- ALT, AST.

- Serum creatinine.

- Random blood sugar.

- ECG for patients above 40 years and to those with history of cardiac troubles.

- Plain chest x-ray for heavy smokers, hypertensive patients and those with chest signs.

- Magnetic resonance imaging was done when necessary.

\section{Ethical approval}

The study was approved by the Ethical Committee of Department of Surgery of Al-Azhar University.

The technique was explained to the patients who accepted it with a written consents.

\section{C-Preoperative preparation:}

All patients were admitted to the hospital at least one day before surgery, the anal region was shaved on the morning of the operation, and the rectum was evacuated with the aid of a disposable enema.

\section{D-Operative Technique:}

- Examination under anesthesia: All patients were examined under spinal anesthesia in lithotomy position, inspection and identification of the site of external opening was done and proctoscopy was applied for detection of internal opening and the fistula tract.

- Hydrogen peroxide was injected through the external opening of the fistula to locate the internal opening. A malleable metallic probe was inserted through the external opening and directed gently until its end came out through the internal opening of the fistula.

- Using electrocautery, coring of fistulous track around the external opening was conducted until the point where the track passed beneath the external anal sphincter muscles. Prolene No.1 thread was attached to the end of the metallic probe then withdrawn from the external opening along with the probe. The prolene thread was loosely tied around the remaining part of the track and the anal sphincter muscles. Any branches from the primary track were sought and excised with electrocautery, supralevator extension and cavity were carefully curetted with metallic curette then irrigated with normal saline. Hemostasis was ensured then the wound was covered with a sterile compression dressing.

\section{E- Postoperative follow up:}

- Patients were followed in the outpatient clinic every week for the first month after the placement of seton, then at three months, and subsequently every three months.

- Seton was removed after around 3 months upon complete healing of the superficial wound and when there were no signs of perianal discharge; in cases of delayed healing or development of perianal sepsis the removal of seton was postponed.

- Complete healing was defined as complete epithelization of the wound with no evidence of external opening of the fistula or perianal discharge.

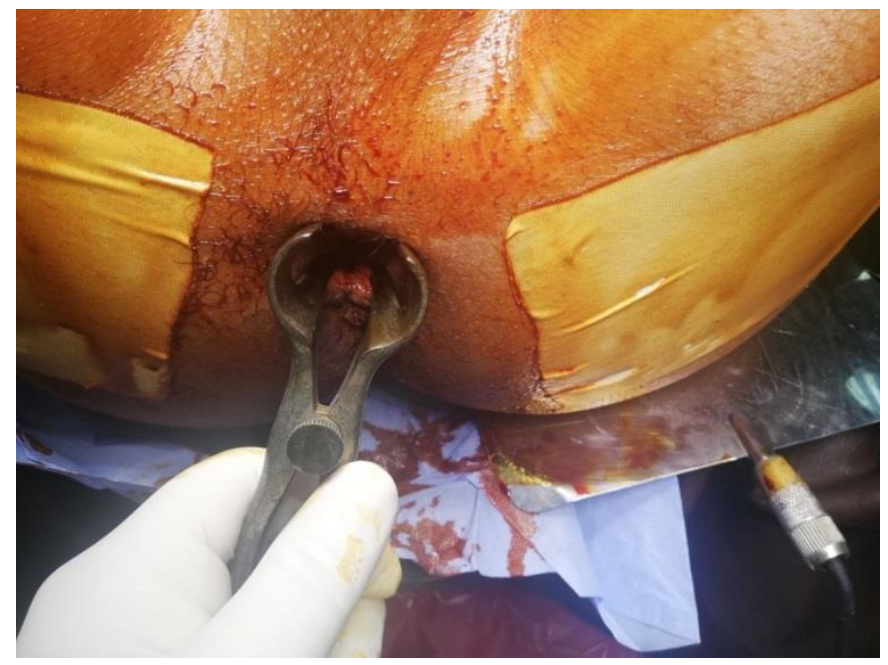

Figure (1): Anal examination under general anesthesia 


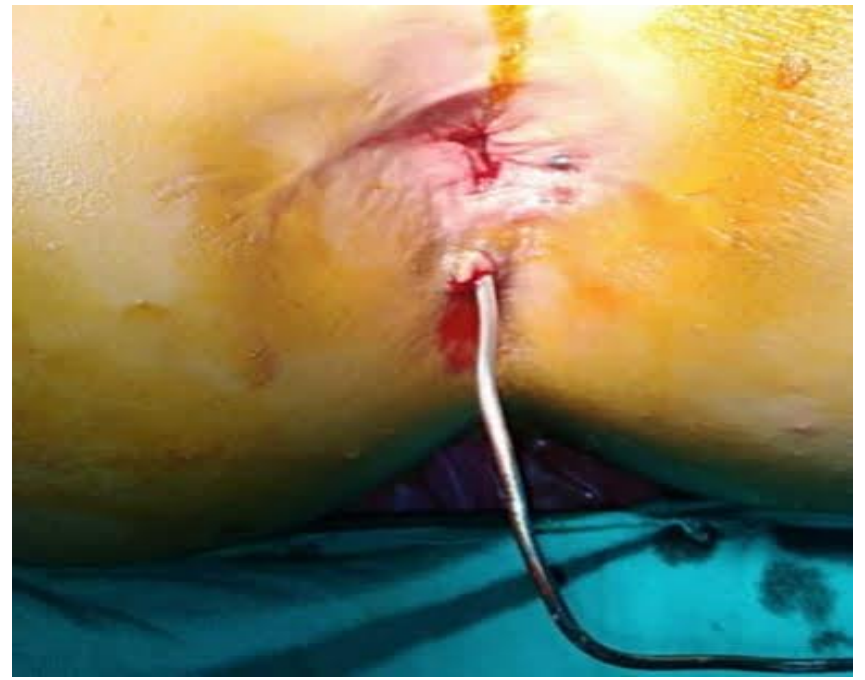

Figure (2): Propping of the fistulous track

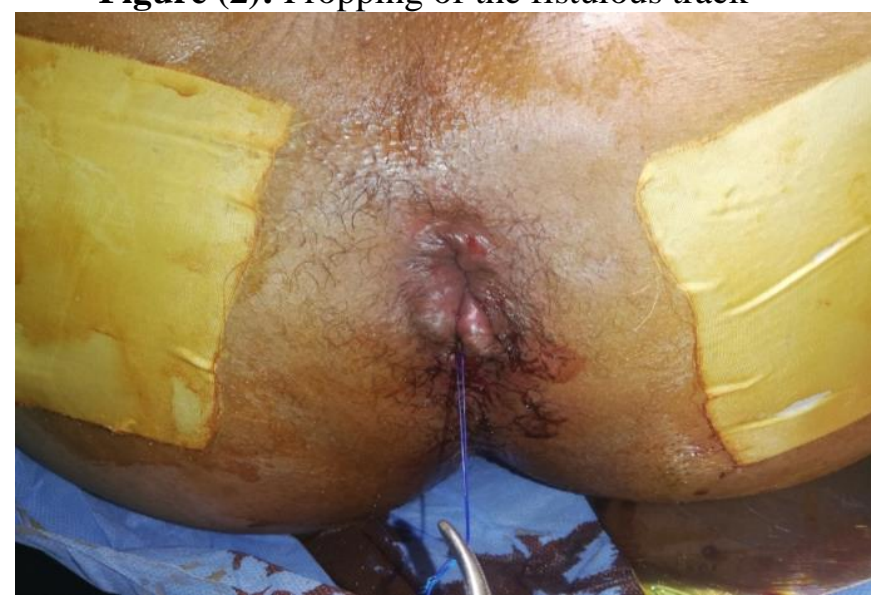

Figure (3): Seton placement

Statistical analysis of the data:
Data were fed to the computer and analyzed using IBM SPSS software package version 20.0 (Armonk, NY: IBM Corp). Qualitative data were described using number and percent. Quantitative data were described using range (minimum and maximum), mean, standard deviation and median. Significance of the obtained results was judged at the $5 \%$ level.

The used tests were:

\section{1 - Chi-square test}

For categorical variables, to compare between different groups

\section{2 - Fisher's Exact}

Correction for chi-square when more than $20 \%$ of the cells have expected count less than 5

\section{3 - Student t-test}

For normally distributed quantitative variables, to compare between two studied groups

\section{4 - Mann Whitney test}

For abnormally distributed quantitative variables, to compare between two studied groups.

\section{RESULTS}

Table (1): Distribution of the studied cases according to recurrence $(\mathbf{n}=\mathbf{5 0})$

\begin{tabular}{|l|c|c||}
\hline Recurrence & No. & \% \\
\hline Recurrence (A) & 6 & 12.0 \\
Non recurrence (B) & 44 & 88.0 \\
\hline
\end{tabular}

The study was submitted on 50 patients, recurrence occurred in 6 patients (Table 1)

Patients were divided into two groups according to recurrence.

Table (2): Comparison between the two studied groups according to demographic data

\begin{tabular}{|c|c|c|c|c|c|c|c|}
\hline & \multicolumn{2}{|c|}{$\begin{array}{c}\text { Total } \\
(\mathbf{n}=\mathbf{5 0})\end{array}$} & \multicolumn{2}{|c|}{$\begin{array}{l}\text { Recurrence }(A) \\
\quad(n=6)\end{array}$} & \multicolumn{2}{|c|}{$\begin{array}{c}\text { Non recurrence }(B) \\
(n=44)\end{array}$} & \multirow[t]{2}{*}{$\mathbf{P}$} \\
\hline & No. & $\%$ & No. & $\%$ & No. & $\%$ & \\
\hline $\begin{array}{l}\text { Sex } \\
\quad \text { Male } \\
\text { Female }\end{array}$ & $\begin{array}{c}43 \\
7\end{array}$ & $\begin{array}{l}86.0 \\
14.0\end{array}$ & $\begin{array}{l}5 \\
1\end{array}$ & $\begin{array}{l}83.3 \\
16.7\end{array}$ & $\begin{array}{c}38 \\
6\end{array}$ & $\begin{array}{l}86.4 \\
13.6\end{array}$ & $\begin{array}{l}{ }^{\mathrm{FE}} \mathrm{p}= \\
1.000\end{array}$ \\
\hline $\begin{array}{l}\text { Age (years) } \\
\text { Min. - Max. } \\
\text { Mean } \pm \text { SD. } \\
\text { Median (IQR) }\end{array}$ & \multicolumn{2}{|c|}{$\begin{array}{c}18.0-60.0 \\
38.96 \pm 8.97 \\
38.50(33.0-44.3)\end{array}$} & \multicolumn{2}{|c|}{$\begin{array}{c}28.0-51.0 \\
39.67 \pm 9.05 \\
37.0(33.3-50.3)\end{array}$} & \multicolumn{2}{|c|}{$\begin{array}{c}18.0-60.0 \\
38.86 \pm 9.06 \\
39.50(33.0-44.0)\end{array}$} & 0.839 \\
\hline
\end{tabular}

FE: Fisher's Exact, The mean age of the patients was $38.96 \pm 8.97$ (Table 2).

Table (3): Comparison between the two studied groups according to external opening of fistula

\begin{tabular}{|c|c|c|c|c|c|c|c|}
\hline \multirow{2}{*}{$\begin{array}{c}\text { External opening of } \\
\text { fistula }\end{array}$} & \multicolumn{2}{|c|}{$\begin{array}{c}\text { Total } \\
(\mathbf{n}=\mathbf{5 0})\end{array}$} & \multicolumn{2}{|c|}{$\begin{array}{c}\text { Recurrence } \\
(\mathrm{n}=6)\end{array}$} & \multicolumn{2}{|c|}{$\begin{array}{l}\text { Non recurrence } \\
\quad(n=44)\end{array}$} & \multirow[t]{2}{*}{${ }^{{ }^{F E}} \mathbf{p}$} \\
\hline & No. & $\%$ & No. & $\%$ & No. & $\%$ & \\
\hline Posterior & 28 & 56.0 & 1 & 16.7 & 27 & 61.4 & 0.075 \\
\hline Anterior & 13 & 26.0 & 4 & 66.7 & 9 & 20.5 & $0.033^{*}$ \\
\hline Lateral & 4 & 8.0 & 0 & 0.0 & 4 & 9.1 & 1.000 \\
\hline Multiple & 5 & 10.0 & 1 & 16.7 & 4 & 9.1 & 0.057 \\
\hline
\end{tabular}

FE: Fisher's Exact, *: Statistically significant at $\mathrm{p} \leq 0.05$

45 patients $(90 \%)$ had fistula with a single external opening and $5(10 \%)$ had multiple external openings 
(Table 3).

Table (4): $\quad$ Comparison between the two studied groups according to type of fistula

\begin{tabular}{|c|c|c|c|c|c|c|c|}
\hline \multirow[t]{2}{*}{ Type of fistula } & \multicolumn{2}{|c|}{$\begin{array}{c}\text { Total } \\
(n=50)\end{array}$} & \multicolumn{2}{|c|}{$\begin{array}{l}\text { Recurrence } \\
\quad(n=6)\end{array}$} & \multicolumn{2}{|c|}{$\begin{array}{c}\text { Non recurrence } \\
(n=44)\end{array}$} & \multirow[t]{2}{*}{${ }^{\mathrm{FE}} \mathbf{p}$} \\
\hline & No. & $\%$ & No. & $\%$ & No. & $\%$ & \\
\hline Transsphincteric & 25 & 50.0 & 2 & 33.3 & 23 & 52.3 & 0.667 \\
\hline Suprasphincteric & 6 & 12.0 & 1 & 16.7 & 5 & 11.4 & 0.556 \\
\hline Intersphincteric & 11 & 22.0 & 0 & 0.0 & 11 & 25.0 & 0.317 \\
\hline Extrasphincteric & 5 & 10.0 & 1 & 16.7 & 4 & 9.1 & 0.487 \\
\hline Horseshoe & 3 & 6.0 & 2 & 33.3 & 1 & 2.3 & $0.035^{*}$ \\
\hline
\end{tabular}

FE: Fisher's Exact, *: Statistically significant at $\mathrm{p} \leq 0.05$

Intraoperative assessment of patients after probing revealed a statistical significant difference in the horseshoe type (Type 4).

Table (5): Comparison between the two studied groups according to seton removal and wound healing

\begin{tabular}{|c|c|c|c|c|}
\hline & $\begin{array}{c}\text { Total } \\
(n=50)\end{array}$ & $\begin{array}{c}\text { Recurrence } \\
(n=6)\end{array}$ & $\begin{array}{c}\text { Non recurrence } \\
(n=44)\end{array}$ & $\mathbf{p}$ \\
\hline $\begin{array}{l}\text { Seton removal (months) } \\
\text { Min. }- \text { Max. } \\
\text { Mean } \pm \text { SD. }\end{array}$ & $\begin{array}{c}2.50-6.0 \\
3.46 \pm 0.82\end{array}$ & $\begin{array}{c}3.0-6.0 \\
4.0 \pm 1.10\end{array}$ & $\begin{array}{c}2.50-5.0 \\
3.39 \pm 0.76\end{array}$ & 0.099 \\
\hline $\begin{array}{l}\text { Wound healing after setor } \\
\text { removal (weeks) } \\
\text { Min. }- \text { Max. } \\
\text { Mean } \pm \text { SD. } \\
\text { Median (IQR) } \\
\end{array}$ & $\begin{array}{c}3.0-7.0 \\
4.50 \pm 1.20 \\
4.0(4.0-5.0)\end{array}$ & $\begin{array}{c}3.0-4.0 \\
3.67 \pm 0.52 \\
4.0(3.0-4.0) \\
\end{array}$ & $\begin{array}{c}3.0-7.0 \\
4.61 \pm 1.22 \\
4.0(4.0-5.0)\end{array}$ & 0.069 \\
\hline $\begin{array}{l}\text { Complete wound healing } \\
\text { (weeks) } \\
\text { Min. }- \text { Max. } \\
\text { Mean } \pm \text { SD. } \\
\text { Median (IQR) }\end{array}$ & $\begin{array}{c}13.0-28.0 \\
17.56 \pm 3.0 \\
17.0 ? ? ?\end{array}$ & $\begin{array}{c}15.0-28.0 \\
20.0 \pm 4.60 \\
20.0 ? ? ?\end{array}$ & $\begin{array}{c}13.0-25.0 \\
17.23 \pm 2.62 \\
17.0 ? ? ?\end{array}$ & 0.127 \\
\hline
\end{tabular}

There was no statistical significance between the 2 groups as regard the mean time for wound healing.

Table (6): Comparison between the two studied groups according to complications

\begin{tabular}{|c|c|c|c|c|c|c|c|}
\hline \multirow[t]{2}{*}{ Complications } & \multicolumn{2}{|c|}{$\begin{array}{c}\text { Total } \\
(n=50)\end{array}$} & \multicolumn{2}{|c|}{$\begin{array}{c}\text { Recurrence } \\
(n=6)\end{array}$} & \multicolumn{2}{|c|}{$\begin{array}{c}\text { Non recurrence } \\
(n=44)\end{array}$} & \multirow[t]{2}{*}{${ }^{\mathrm{FE}_{\mathbf{p}}} \mathbf{p}$} \\
\hline & No. & $\%$ & No. & $\%$ & No. & $\%$ & \\
\hline Wound infection & 3 & 6.0 & 1 & 16.7 & 2 & 4.5 & 0.324 \\
\hline Incontinence & 3 & 6.0 & 1 & 16.7 & 2 & 4.5 & 0.324 \\
\hline
\end{tabular}

\section{FE: Fisher's Exact}

Postoperative complications are in table 6.

\section{DISCUSSION}

Our study was a prospective study, on a sample size of 50 patients (43 males and 7 females) of high perianal fistula, carried on Bab-Alsharia University hospital, the mean age was $38.96 \pm 8.97$.

The overall recurrence rate in our study was $12 \%$ (6/50) patients. According to Emile et al. ${ }^{(6)}$ on his study the overall recurrence rate was $10 \%$. According to Eitan et al. ${ }^{(10)}$ on his study the overall recurrence rate was $19.4 \%$. This variation in the recurrence rates can be attributed to the different indications and methods employed for seton placement as well the type of seton itself.

In our study history of abscess drainage was present in (45/50) patients $90 \%$, recurrence occurred in 6 patients of them but 39 of them had no recurrence and there was no statistical significance.

In our study there was (14/50) patients $28 \%$ had previous surgical intervention for perianal fistula, recurrence occurred in 4 patients which was $66.7 \%$ 
of recurrent cases and no recurrence in 10 patients. Coping with Emile et al. ${ }^{(6)}$ on his study patients who had history of previous fistula surgery represented $69.2 \%$ of recurrent cases. According to Visscher et al. (12) on his study patients who had history of previous fistula surgery represented $75 \%$ of recurrent cases. This high risk for recurrence in patients who had history of previous fistula surgery is due to fibrosis of the area and loss of anatomical land marks which led to miss of branches or extensions of the 1ry track and made the surgery more difficult. This was statistically significant.

In our study 45 patients (90\%) had fistula with a single external opening and $5(10 \%)$ had multiple external openings. The external opening was situated anterior in $13(26 \%)$ patients, recurrence occurred in 4 patients $(66.7 \%)$ of recurrent cases. According to Emile et al. ${ }^{\left({ }^{(6)}\right.}$ on his study the external opening was anterior in $(53.8 \%)$ of recurrent cases. Compatible with Memon et al. ${ }^{(13)}$; on his study the external opening was anterior in (75\%) of recurrent cases, and it was statistically significant.

Intraoperative assessment of type of fistula in our study revealed that 3 patients had horseshoe fistula, recurrence occurred in 2 patients of them which represented (33.3\%) of recurrent cases. According to Emile et al. ${ }^{(\boldsymbol{6})}$ on his study patients who had horseshoe fistula represented 4/26 (15.3\%) of recurrent cases, and it was statistically significant.

In our study there were $7 / 50$ patients had supralevator extension of the fistulous track, recurrence occurred in 3 patients which was $50 \%$ of recurrent cases and 4 patients had no recurrence. According to Emile et al. ${ }^{(6)}$ on his study patients with supralevator extension represented $34.6 \%$ of recurrent cases. This was statistically significant

In our study the mean time for seton removal was 3.4 0.8 months and seton removal was postponed in cases of delayed healing or development of perianal infection, the mean time for wound healing after seton removal in all patients was $4.50 \pm 1.20$ weeks and finally it was found that mean time for complete wound healing was $17.56 \pm 3.0$ weeks.

Fecal incontinence was recorded in 3/50 (6\%) patients in our study. According to Emile et al. ${ }^{(6)}$ on his study incontinence occurred in 3\% of patients. According to Vatansev et al. ${ }^{(14)}$ on his study incontinence occurred in $15.6 \%$ of patients. Factors associated with higher rates of FI after fistula surgery include high transsphincteric or suprasphincteric fistula, horse-shoe fistula, and patients older than 45 years $^{(\mathbf{1 5 )}}$ and this is in line with our study.

It is worthy to imply the alternative sphinctersaving options in the cases of high perianal fistula. The injection of fibrin glue, despite being costly, has emerged as a promising solution for the management of complex anal fistula; however, a meta-analysis by Cirocchi et al. (16) demonstrated that fibrin glue injection had higher recurrence rate than the conventional surgical therapy (54\% vs $47 \%$ ) with more or less equal incidence of postoperative FI. Loungnarath and colleagues reported even higher recurrence rate $(69 \%)$ after the use of fibrin glue injection in complex FIA $^{(\mathbf{1 7})}$.

It is worthy to note that the present study is a single-institution study evaluating predictors of recurrence after one surgical technique, therefore it does not reflect the entire surgical practice of anal fistula. Multi-center randomized trials comparing different techniques for high anal fistula are required to determine the significant predictors of recurrence after each procedure in a statistically sound manner.

\section{CONCLUSION}

In conclusion, the results of our study asserted the previously reported satisfactory outcome of seton placement in high perianal fistula. The relatively high rate of fistula recurrence observed in our study can be attributed to the fact that about $30 \%$ of the cases were already recurrent after previous surgery. On the other hand, the incidence of postoperative FI was much lower than what was formerly reported.

Factors that significantly predicted the recurrence of FIA were previous fistula surgery, anterior anal fistula, and presence of secondary tracks or branches as with supralevator extension, and horseshoes fistula. Female patients and horse-shoe fistula were the significant risk factors for developing FI after the placement of seton.

\section{REFERENCES}

1. Tozer P, Sala S, Cianci V et al. (2013): Fistulotomy in the tertiary setting can achieve high rates of fistula cure with an acceptable risk of deterioration in continence. $\mathbf{J}$ Gastrointest Surg., 17:1960-65.

2. Farquharson M, Moran B (2005): Surgery of the anus and perineum. In: Farquharson, M. and Moran, B. (eds): Farquharson's textbook of operative general surgery. $9^{\text {th }}$ ed.Boca Raton, FL: CRC press, Pp. 445.

3. Fazio VW, Church JM, Delaney CP (2005): Current Therapy in Colon and Rectal Surgery. $2^{\text {nd }}$ ed. Philadelphia: Elsevier Mosby, Pp.255-62.

4. Lunniss PJ, Phillips RK (2014): Anal fistula: evaluation and management. In:Phillips, R.K.S. and Clark, S. (eds): Colorectal Surgery: A Companion to Specialist Surgical Practice. $5^{\text {th }}$ ed. China: Elsevier, Pp. 212-30.

5. Williams JG, Farrands PA, Williams AB et al. (2007): The Treatment of Anal Fistula: ACPGBI Position Statement. Int J Colorectal Disease, 9(4): 18-50.

6. Emile SH, Elfeki H, Thabet W et al. (2017): Predictive Factors for Recurrence of High Trans-sphincteric Anal Fistula after Placement of Seton. J Surg Res., 213:261-8.

7. Blumetti J, Abcarian A, Quinteros F et al. (2012): 
Evolution of treatment of fistula in ano. World J Surg., 36(5):1162-7.

8. Abbas MA, Lemus-Rangel R, Hamadani A (2008): Long-term outcome of endorectal advancement flap for complex anorectal fistulae. Am Surg., 74(10):921-4.

9. Awad ML, Sell HW, Stahlfeld KR (2009): Split-shot sinker facilitates seton treatment of anal fistulae. Colorectal Dis., 11:524-6.

10. Eitan A, Koliada M, Bickel A (2009): The use of the loose seton technique as a definitive treatment for recurrent and persistent high trans-sphincteric anal fistulas: a long-term outcome. J Gastrointest Surg., 13:1116.

11. Kaiser AM (2008): The McGraw-Hill Manual of Colorectal Surgery. New York: McGraw-Hill., Pp. 211220.

12. Visscher AP, Schuur D, Slooff RA et al. (2016): Predictive factors for recurrence of cryptoglandular fistulae characterized by preoperative three-dimensional endoanal ultrasound. Colorectal Dis., 18(5):503-9.

13. Memon AA, Murtaza G, Azami R et al. (2011): Treatment of complex fistula in ano with cable-tie seton: a prospective case series. ISRN Surg., 2011:636-9.

14. Vatansev C, Alabaz O, Tekin A et al. (2007): A new seton type for the treatment of anal fistula. Dig Dis Sci., 52: $1920-3$

15. Abbas MA, Jackson CH, Haigh PI (2011): Predictors of outcome for anal fistula surgery. Arch Surg., 146(9):1011-6.

16. Cirocchi R, Santoro A, Trastulli S et al. (2010): Metaanalysis of fibrin glue versus surgery for treatment of fistula-in-ano. Ann Ital Chir., 81(5):349-56.

17. Loungnarath R, Dietz DW, Mutch MG et al. (2004): Fibrin glue treatment of complex anal fistulas has low success rate. Dis Colon Rectum, 47: 432-6. 